There was marked hyperæmia of the nasal and pharyngeal mucous membranes, and epistaxis was repeated and troublesome. Headache and sleeplessness were the other chief features. The rash clisappeared slowly, and on its disappearance fleeting pains in the joints were manifest. There was no albuminuria throughout. For ten days after the temperature had subsided there was a distinct feeling of malaise; then occurred a terminal rise with complete recovery. Four weeks from the date of onset desquamation was taking place on the palms of the hands. The only possible source of infection was a visit to the dentist, and recently it has transpired that he took to bed with a sharp attack of dengue fever immediately after J. D.'s visit.

I am, Sir, yours faithfully,

Khanka, Cairo, Feb. 16th, 1920. $\quad$ R. S. MILLER, M.D.

\section{THE NOMENCLATURE OF TRYPANOSOMES : A CORRECTION.}

To the Editor of THE LANCET.

SIR,-In my letter, as published in your issue of Feb. 21st, the word "Trypocastellanellea" is made to appear a little longer than it actually is ; an additional "an" has crept into it inadvertently and in the wrong place. I remember that I found the word somewhat difficult to type, and I can only express my regret if I overlooked the mistake in the proof. The word is printed correctly, however, in the paragraph dealing particularly with it.

I will take this opportunity of adding that I hope it was quite clear that my letter was not intended as an argument either in favour of, or against, the actual classificatory changes proposed-whether generic or specific. My only object was to protest against a growing tendency to (as I regard it) travesty scientific nomenclature in connexion with the protozoa. Personally, I would much prefer to continue to call such well-known parasites as Trypanosoma lewisi and T. gambiense by these names than to have to think of them as Lewisonella lewisi and Castellanella castellanii respectively. It may be noted that Professor Minchin, although he recognised that Babesia was most probably the correct name, preferred to use Piroplasma, and in his book he put the latter name first in his account of this genus (p. 379). If Babesia has to stand, the result is, that of all the types into which this important group has been subdivided there is only the doubtful "Anaplasma" whose generic name gives us any idea of what kind of creature is concerned! Is not this an absurdity to be avoided in the future?

Feb. 26th, 1920.

I am, Sir, yours faithfully,

H. M. WOODCOCK.

** The error was in the original manuscript and remained uncorrected in the proof, an oversight committed as much by ourselves as by the author.-ED. $\mathrm{L}$.

DeATH of Mr. C. GoRdon HewitT.-The death is announced of Charles Gordon Hewitt, D.Sc., F.R.S.C., Dominion Entomologist in Canada, and formerly lecturer in economic zoology in the University of Manchester. Mr. Hewitt was a recogoised authority on the relation of houseflies to disease, his papers on this subject appenring in a book entitled "The House-Fly," published at the Cambridge University Press in 1914. During the war leaflets from his pen on the suppression of insects affecting troops were issued by the Canadian Department of Agriculture. His intimate entomological knowledge was placed freely at the service of humanity.

Liverpool Hospital for Cancer and Skin DISHASES. - The anuual meeting of this hospltal was helid in the Town Hall on Feb. 27th. The report showed that the number of attendances recorded-37,610-was an increase of 7395 on the figures of the previous year. The average daily number of beds occupied by in-patients was 19 as cumpared with 14. Uufortunately the finances have not increased in a corresponding ratio, and the bunk overdraft now stands at close ou $£ 4000$. Like all other volentary bospitals, this institution is suffering from the uncertainty which prevals as to the future of the voluutary principle. The Lord May or, who presided, expressed the bope that wheu the handsome sum, subscribed through the appeal of the late Lord Mayor came to be divider, the strain on this hospital's funds would be considerably relieved.

\section{agarliamrentary a antelligemes.}

\section{NOTES ON CURRENT TOPICS.}

Awards for Medical Discoveries.

A Deputation from the Medical Committee of the Honse of Commons was received by Mr. BALFour (Lord President of the Council) on Tuesday, March 2ad, to urge upon the Government the establishment of a scheme of awards for medical and scientific discoveries. The suggestion put forward by the deputation was that $£ 20,000$ a year should be devoted to giving awards on similar lines to the Nobel prizes. Mr. BALEOUR received the proposal spmpatbetically, but pointed out that the settlement of who had actually made a particular discover might be a difficult matter. In his view a better plan would be to place investigators in a more comfortable position for carrying out their research work.

The New Insurance Bill.

Although the text of the new National Health Insurance Bill has not yet been published, it is nnderstood that the measure does not alter the general scope of medical benefit. Regulations, however, will follow as a result of it which will involve considerable modifications, the object of which is to improve the standard of medical services in conpexion with insurance and to simplify its administration. Under the new regulations a limit is to be placed on the number of patients for whom a doctor can be responsible singlehanded. A national maximum of 3000 has been fixed. The scope of free choice of doctor is to be enlarged, and there will be a half-yearly choice instead of a yearly choice. Obligations are to be leid on medical men to give emergency treatment and to provide proper surgery and waiting-room accommodation.

\section{HOOBE OF COMMONS.}

Tuesday, Feb. 24TH.

Morphia, Morphia Salts, and Opium.

Mr. GILbert asked the Parliamentary Secretary of the Board of Trade what was the total amount of morphia of British manufacture exported in the year 1919; what amount was exported to Japan aud the United States respectively; whether the amounts included consignments by po: $t$; and what amount of opium was imported from India, Persia, and Turkey respectively into Great Britain during the year 1919.-Mr. BRIDGEMAN replied: The quantity of morpbia and morphia salts registered as exported from the Uniter Kingdom in the year 1919 was $322,970 \mathrm{oz}$., of which $121,474 \mathrm{oz}$. went to the Uaited States of America. The records show that no morphia and morphia salts were exported to Japan. No particulars are available with regard to consignments by post. The quantities of opium registered as imported iuto the United Kingdom during the year 1919 from British India, Yersia, and Turkey respectivelv were as follows: British India, 466,475 $\mathrm{lb}$; Persia, 30.558 lb.; European Turkey, 204,966 lb.; Asiatic Turkey, 133,157 lb.

$$
\text { Arsenical Treatment of Syphilis. }
$$

Mr. WATERSON asked the Minister of Health whether his attention had been drawn to the particulars as to a largo number of deaths of soldiers after arsenical treatment for syphilis given in the paper read by Brevet-Colonel $L$. W. Harrison at a meeting of the British Medical Association in April, 1919; whether any special inquiries had been made into the cause of the deaths in question; and, if so, whether it was proposed to publish the results of the inquiries, $-\mathrm{Dr}$. ADDISON replied: The answer to the first part of tne question is in the affirmative. A special committee appointed by the Medical Research Committee is inquiring inter alia into the toxic effects of arsenobenzol compounds, and I understand that the report of the Committee will be published in dne course.

Mr. WATERSON asked the Minister of Health whether he had obtalned a copy of the report of the commission which sat in Germany to inquire into the cause of toxic effects produced by the arsenlcal treatment of syphilis; and, if so, would he arrauge for a translation or a résumé of it to be published.-Dr. ADDISON replied: I have taken steps to procure the report in question, and when I have received it I will consider what I can do to meet the request of the honourable Member.

$$
\text { Medical Officer's Demobilisation. }
$$

Mr. ROYCE asked the Secretary of State for War whether cable was sent to Mesopotamia in May last ordering the demobilisation of Captaín R. Gillespie Smith, Royal Army Medical Corps; and, if so, why was the order not carried out and could he state if this officer was still in Mesopotamis. -Mr. ChURChILL replied: The answer to the first part of 